\title{
RANCANG BANGUN APLIKASI KARTU MENUJU SEHAT (e-KMS) PADA PLATFORM ANDROID
}

\author{
Kurnia Muludi1), Noni Kurniasih'2), Aristoteles ${ }^{3)}$ dan Muhammad Iqbal4) \\ 1,2,3,4) Jurusan Ilmu Komputer, Fakultas Matematika dan Ilmu Pengetahuan Alam, \\ Universitas Lampung \\ Jl. Prof. Dr. Soemantri Brodjonegoro No. 1, Bandar Lampung 35145 \\ e-mail: 1) kmuludi@fmipa.unila.ac.id, 2) noni.kurniasih1103@gmail.com, 3) aristo- \\ teles.1981@fmipa.unila.ac.id, ${ }^{4)}$ muhammadiqbal@fmipa.unila.ac.id
}

\begin{abstract}
Toddler Growth Chart held by parents is a book that consists of a toddler's growth history which holds by Maternal and Child Health Services (Posyandu) officer. Growth Chartbook still uses traditional ways, written by hands to records all of the toddler's growth. Posyandu reports that sent to the Public Health Center (Puskesmas) every month still proceeds with a spreadsheet, and it makes Posyandu officers felt the difficulty of processing the data, like record, search, and store the data. e-KMS Apps can help Posyandu officers for easy recording and searching, and tracing data history. It also helps Posyandu officers to make Posyandu reports easily. This app helps toddler's parents to control their toddler's growth and make the parents feel easy about how to take care of the toddlers.

This application is equipped with features of calculating nutrition status and presenting toddler nutrition status data in the graph based on WHO (World Health Organization) standards in 2006, Posyandu activities, calculation of nutritional status for parents of children under five to be able for knowing the nutritional status of toddlers anywhere and at any time without waiting for the Posyandu schedule. It also provides tips and tricks for caring for toddlers to inform parents how to care for toddlers, and manages Posyandu reports every month to control the condition of toddlers.
\end{abstract}

Keywords: Android, Growth Chart, Nutritional Status, Child Health Service.

\begin{abstract}
Abstrak
Kartu Menuju Sehat (KMS) merupakan kartu yang berisi data kesehatan bayi secara berkala yang dipegang oleh orang tua. Pembukuan data ini mempersulit kader posyandu dalam pencatatan, pencarian dan penyimpanan data Balita. Selama ini Laporan Posyandu dikumpulkan ke Puskesmas pada tiap bulan dan diolah menggunakan spreadsheet. Tidak jarang cara ini sering mengakibatkan proses pengiputan mengalami kesalahan. Aplikasi mobile KMS (e-KMS) dapat mempermudah kader Posyandu dalam proses di atas sekaligus dapat mengelola laporan Posyandu dengan lebih mudah. Aplikasi ini juga mempermudah orang tua dalam memonitor kondisi perkembangan balita dan mengetahui bagaimana cara merawat balita. Fitur-fitur lain yang disediakan pada e-KMS diantaranya adalah perhitungan status gizi dan penyajiannya dalam bentuk grafik menggunakan standar WHO (World Health Organization), dan informasi kegiatan Posyandu. Tips dan trik merawat balita disediakan juga untuk memberi membantu pada orang tua cara merawat Balita.
\end{abstract}

Kata Kunci: Android, KMS (Kartu Menuju Sehat), Posyandu, status gizi balita. 


\section{PENDAHULUAN}

Posyandu adalah sistem pelayanan yang dipadukan antara satu program dengan program lainnya yang merupakan forum komunikasi pelayanan terpadu dan dinamis seperti halnya program Keluarga Berencana (KB) dengan kesehatan atau berbagai program lainnya yang berkaitan dengan kegiatan masyarakat [1].

Pelayanan yang diberikan di Posyandu bersifat terpadu, hal ini bertujuan untuk memberikan kemudahan dan keuntungan bagi masyarakat karena di Posyandu tersebut masyarakat dapat memperolah pelayanan lengkap pada waktu dan tempat yang sama. Kontribusi Posyandu dalam meningkatkan kesehatan bayi dan anak balita sangat besar, namun sampai saat ini kualitas pelayanan Posyandu masih perlu ditingkatkan [2].

Posyandu dilaksanakan setiap bulan untuk mengontrol dan menentukan status gizi balita. Indikator paling sederhana dalam menentukan status gizi balita adalah Parameter yang paling mudah dan sesuai untuk metode tersebut adalah berat badan, tinggi badan, dan umur. Hasil penimbangan berat badan di Posyandu kemudian didokumentasikan pada Kartu Menuju Sehat (KMS). KMS merupakan kartu yang memuat kurva pertumbuhan normal anak berdasarkan indeks antropometri berat badan menurut umur yang dibedakan berdasarkan jenis kelamin.

Pengisian KMS yang dilakukan oleh kader Posyandu masih ditulis tangan sehingga mempersulit kader dalam proses pencatatan dan perhitungan menentukan status gizi. Pengisian buku registrasi balita juga masih menggunakan pembukuan jadi mempersulit kader dalam proses pencatatan, penyimpanan dan pencarian data. Laporan Posyandu yang harus dikumpulkan setiap bulannya masih di input menggunakan Mirosoft Excel jadi kader atau bidan Posyandu terkadang mengalami kesalahan dalam proses penginputan karena harus menginput data satu per satu. KMS yang dipegang orang tua Balita yang berisi tentang grafik status gizi Balita setiap bulannya yang digunakan untuk mengontrol kondisi Balita masih menggunakan kertas, jadi data mudah sekali hilang.

Berdasarkan permasalahan di atas maka dibangun aplikasi e-KMS berbasis Android. Aplikasi ini ditujukan mengganti media kertas yang selama ini digunakan dengan sebuah aplikasi yang memiliki fitur pengisian data Balita, laporan Posyandu, Grafik status gizi Balita, dan tips \& trik merawat Balita.

Tujuan dari penelitian ini adalah merancang dan membangun sebuah aplikasi e-KMS pada platform Android untuk mengelola data balita, mengelola data Imunisasi Balita, mengelola kegiatan posyandu, menyimpan data berat dan tinggi badan Balita, menghitung berat badan ideal Balita, imunisasi, Kegiatan Posyandu, grafik status gizi Balita, dan pembuatan laporan posyandu.

\section{METODE}

\subsection{Metode Pengembangan}

Penelitian ini menggunakan metode pengembangan Extreme Programming seperti yang disajikan dalam Gambar 1. 


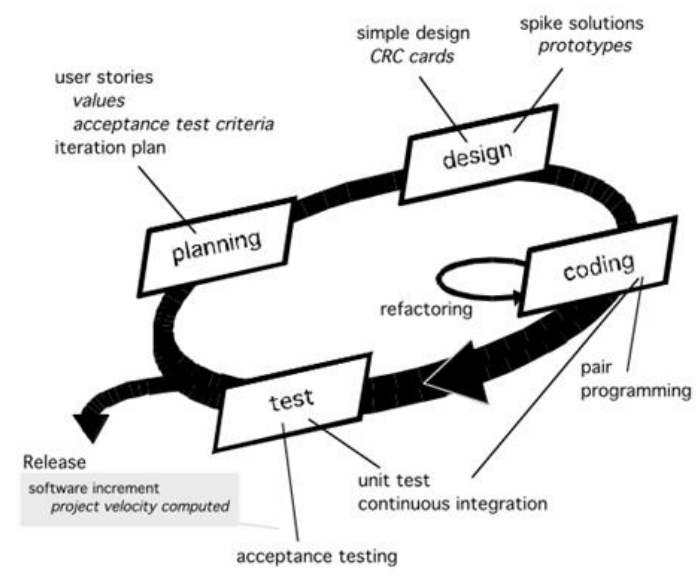

Gambar. 1. Tahapan Pada Model Extreme Programming (XP)

Tahapan yang ada pada model Extreme Programming (XP) adalah sebagai berikut:

a. Planning

Planning activities dimulai dengan team mengumpulkan segala sesuatu kebutuhan yang diperlukan dalam pengembangan aplikasi. Setelah mengumpulkan kebutuhan, team mulai melakukan penyusunan user stories untuk menggambarkan output apa yang diperlukan, fitur, dan kegunaan.

c. Design

Proses desain pada XP menerapkan prinsip Keep It Simple (KIS). Desain yang sederhana biasanya lebih disukai dibandingakan dengan desain yang kompleks dan desain tersebut harus mengikuti stories yang telah dibuat sebelumnya.

d. Coding

Pada tahap ini, terdapat proses refactoring. Refactoring merupakan proses mengubah sistem perangkat lunak dimana struktur code berubah dan menjadi sederhana namun hasil akhir yang dihasilkan sama. Setelah penulis menyelesaikan tahap planning dan design sebaiknya penulis melakukan pengetesan pada setiap unit yang terdapat pada stories terlebih dahulu sebelum memulai pengkodean. Kemudian penulis dapat fokus kembali di dalam pengkodean.

e. Testing

Pada tahap ini acceptance tests atau customer tests melakukan pengujian terhadap program yang telah selesai [3].

Penelitian dilakukan berdasarkan diagram alir yang terdapat pada Gambar 2. Penjelasan dari diagram alir metodologi penelitian pada Gambar 2 adalah sebagai berikut. 


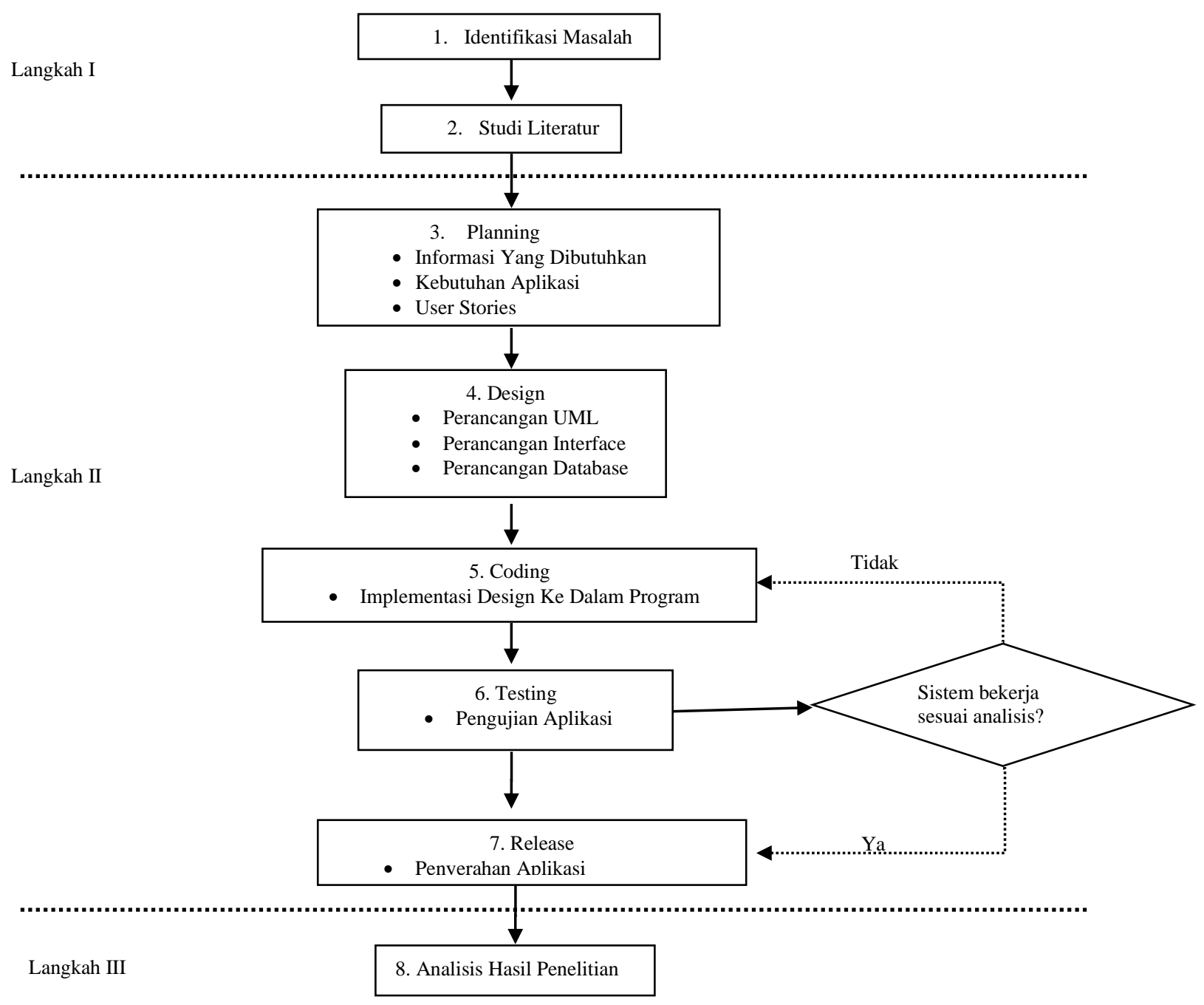

Gambar. 2. Diagram Alir Metodologi Penelitian.

Penjelasan dari diagram alir metodologi penelitian sebagai berikut :

a. Planning

Pada tahap planning ditujukan untuk mengumpulkan kebutuhan yang digunakan untuk pembuatan sistem. Data berupa buku registrasi yang dimiliki oleh kader serta buku KMS (Kartu Menuju Sehat) yang dimiliki oleh ibu balita. Selain itu dilakukan wawancara kepada bidan, kader, dan ibu balita untuk mengetahui informasi alur dari Posyandu.

b. Desain

Pada tahap ini dilakukan dengan pembuatan desain UML (Unified Modeling Language) dan desain interface. Pada pembuatan desain UML membuat use case diagram, class diagram, sequence diagram dan activity diagram. 
c. Coding

Coding dilakukan untuk platform android menggunakan bahasa Java. Sebelum proses pengkodean, database sqlite dibuat terlebih dahulu baru dilakukan proses penulisan program.

d. Testing

Pada tahap testing dilakukan proses pengujian setelah aplikasi jadi, tahap testing ini melibatkan ibu balita dan kader sebagai user untuk menguji aplikasi yang telah jadi.

\section{HASIL DAN PEMBAHASAN}

\subsection{Diagram Use Case}

Use case merupakan pemodelan untuk kelakuan (behavior) sistem informasi yang akan dibuat [4]. Use case diagram berisikan fungsionalitas dari aplikasi eKMS. Pada kader Posyandu aplikasi dapat mengolah semua kegiatan yang ada di Posyandu seperti pengisian KMS, pengisian data imunisasi, kegiatan Posyandu, dan pembuatan laporan Posyandu. Pada aplikasi yang digunakan pada orang tua berisikan data KMS (Kartu Menuju Sehat), penyimpanan data imuniasasi, penyimpanan data balita, dan trik merawat bayi.

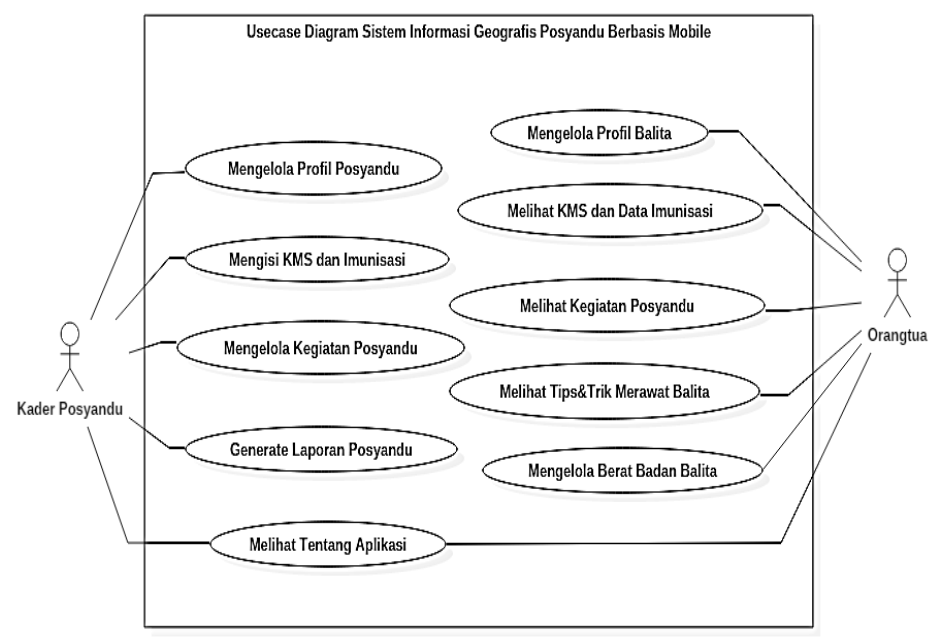

Gambar. 3. Diagram Use Case Aplikasi e-KMS

\subsection{Interface Aplikasi e-KMS}

\subsubsection{Aplikasi e-KMS pada Akun Orang Tua Balita}

a. Tampilan Menu Utama Aplikasi

Tampilan menu utama terdapat 6 menu yang dapat digunakan oleh pengguna, yaitu menu Profile Balita, KMS dan Imunisasi, Kegiatan Posyandu, Kelola Berat Badan Balita, Tips dan Trik Merawat Balita, Lokasi Posyandu, dan Tentang Aplikasi. Pengguna dapat memilih salah satu menu yang akan digunakan untuk mendapat informasi. Tampilan menu utama pengguna dapat dilihat pada Gambar 4. 

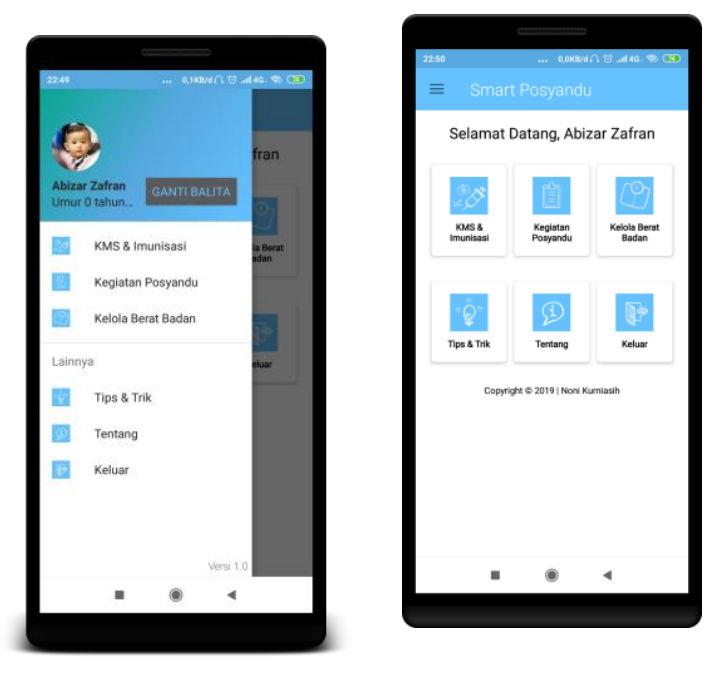

Gambar. 4. Tampilan Halaman Utama

b. Tampilan Halaman Melihat KMS dan Imunisasi

Melihat KMS dan Imunisasi merupakan menu kedua dari aplikasi e-KMS, pada menu ini pengguna dapat melihat infomasi detile tentang infomasi KMS yang berisi grafik tumbuh kembang balita secara lengkap setiap bulannya dan Imunisasi balita yang telah dilakukan. Tampilan melihat KMS dan Imunisasi dapat dilihat pada Gambar 5.

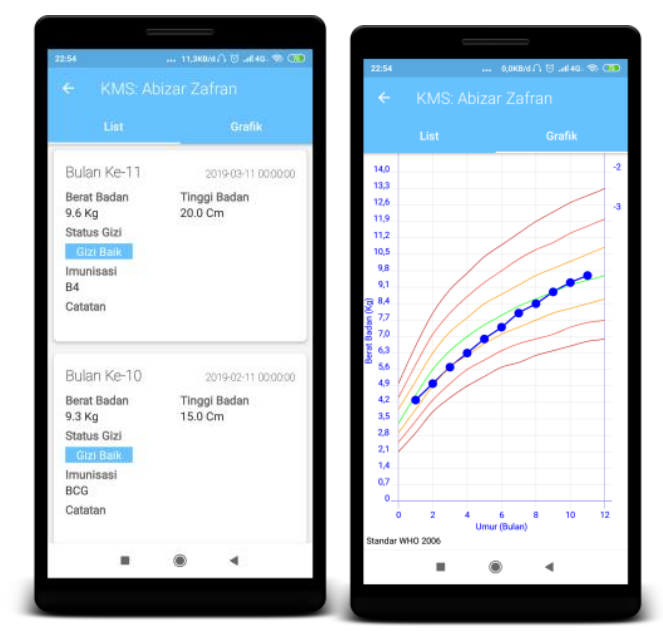

Gambar. 5. Tampilan Halaman KMS dan Imunisasi

c. Tampilan Melihat Kegiatan Posyandu

Kegiatan Posyandu berisi Informasi kegiatan yang diadakan di Posyandu, kegiatan Posyandu akan diisi oleh kader Posyandu yang nantinya akan muncul di aplikasi balita. Tampilan melihat kegiatan Posyandu dilihat pada Gambar 6. 


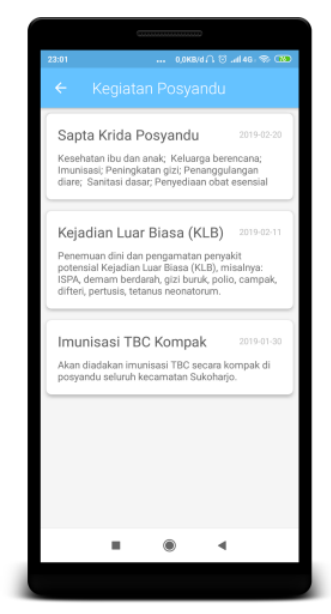

Gambar. 6. Tampilan Halaman Melihat Kegiatan Posyandu

d. Tampilan Menu Mengelola Berat Badan

Pada menu ini pengguna dapat melakukan pengisian data berat badan dan tinggi badan balita untuk mengetahui status gizi Balita. Tampilan mengelola berat badan balita dapat dilihat pada Gambar 7.
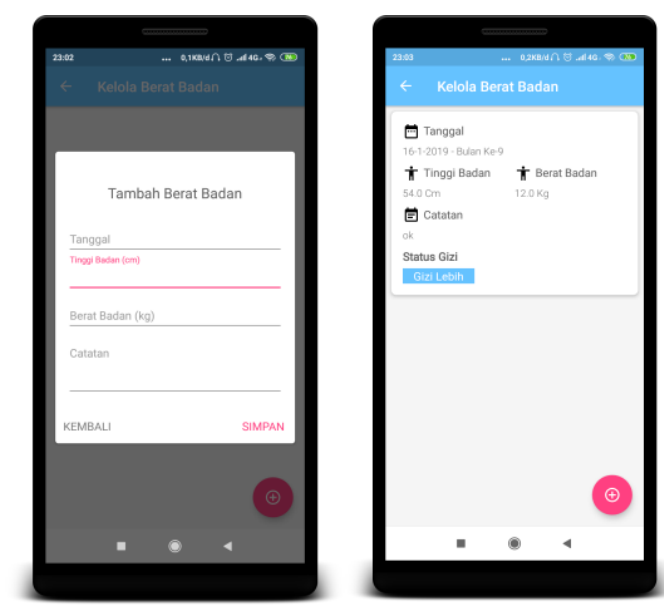

Gambar. 7. Tampilan Halaman Mengelola Berat Badan

e.Tampilan Halaman Tips dan Trik

Pada menu ini berisi informasi cara merawat Balita dari umur 0 bulan sampai dengan 5 tahun, infomasi tersebut meliputi cara memandikan balita, memberi ASI balita, memberi makan balita, tips untuk merawat balita jika sakit, dan lainlain. Tampilan tips dan trik merawat Balita dapat dilihat pada Gambar 8. 


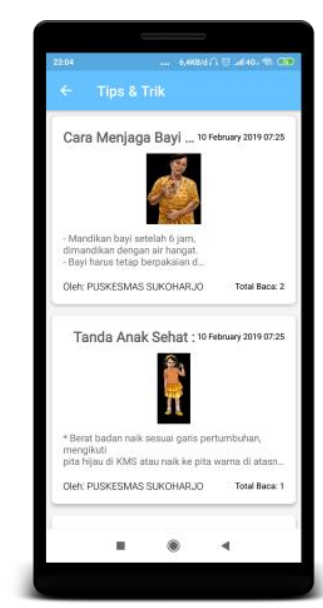

Gambar. 8. Tampilan Halaman Tips dan Trik.

3.2.2 Tampilan Manu Utama Aplikasi Kader Posyandu

a. Tampilan Manu Utama Aplikasi Kader Posyandu

Tampilan menu utama terdapat 5 menu yang dapat digunakan oleh kader Posyandu, yaitu menu Profile Posyandu, KMS dan Imunisasi, Kegiatan Posyandu, Laporan Posyandu, dan Tentang Aplikasi. Kader Posyandu dapat memilih salah satu menu yang akan digunakan untuk mendapat informasi. Tampilan menu utama pengguna dapat dilihat pada Gambar 9.

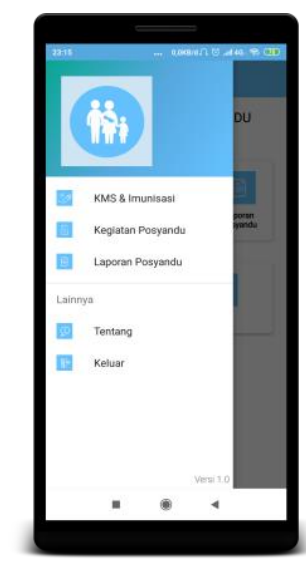

Gambar. 9. Tampilan Halaman Menu Utama Kader Posyandu

b. Tampilan Menu KMS dan Imunisasi Kader Posyandu

Pada menu ini Kader Posyandu mencari data balita sesuai dengan Nomor Identitas Balita dan mengisi umur, berat badan, tinggi badan dan Imuniasasi Balita kemudian akan secara otomatis tersimpan dan dapat mengetahui status gizi dari Balita. Tampilan KMS dan Imunisasi dapat dilihat pada Gambar 10. 


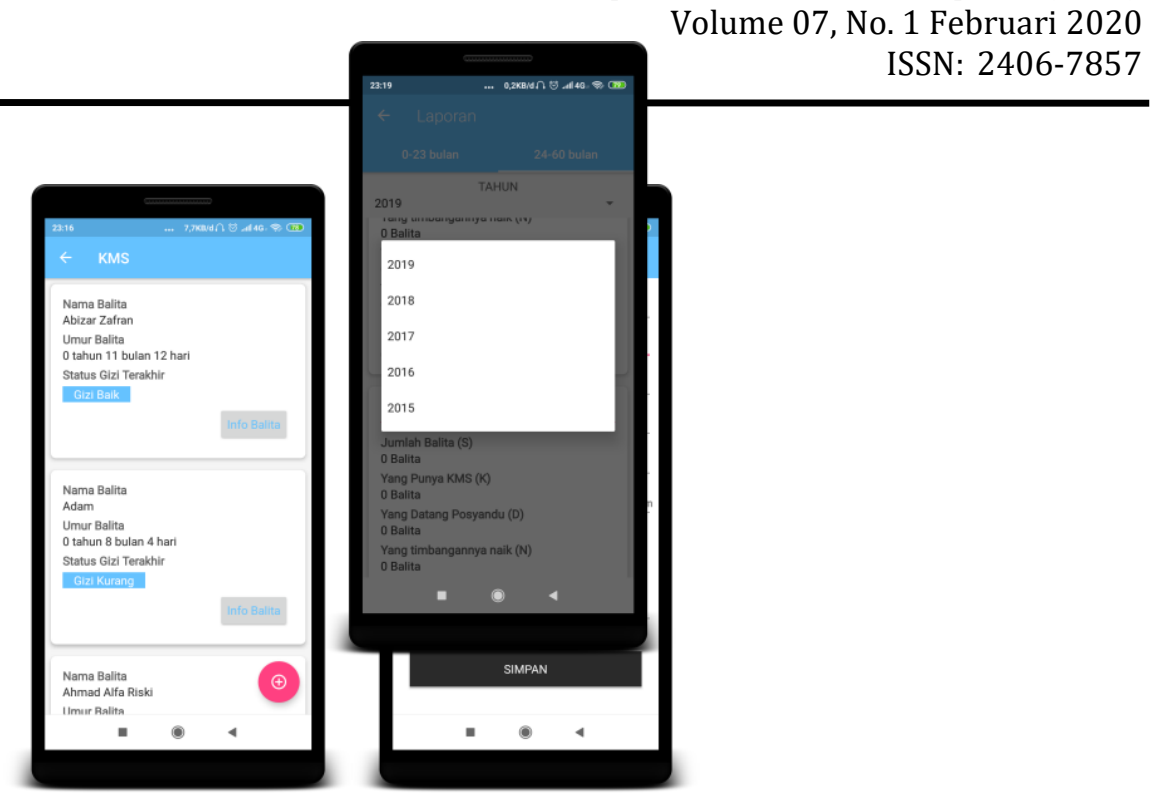

Gambar. 10. Tampilan Halaman Menu KMS dan Imunisasi Kader Posyandu

c. Tampilan Halaman Mengelola Kegiatan Posyandu

Pada menu ini kader Posyandu akan menginputkan kegiatan yang berada di Posyandu seperti jadwal Posyandu, Pengumuman Posyandu, dan lain-lain. Tampilan kegiatan Posyandu dapat dilihat pada Gambar 11.

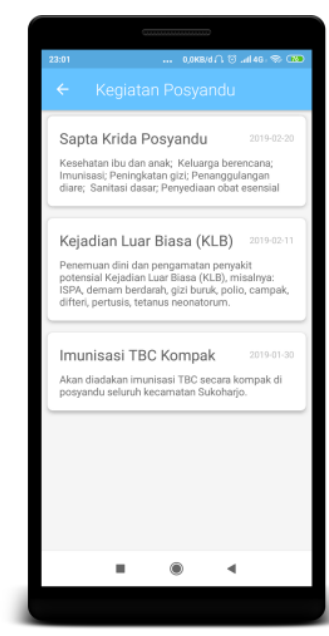

Gambar. 11. Tampilan Halaman Mengelola Kegiatan Posyandu

d. Tampilan Generate Laporan Posyandu

Generate Laporan Posyandu merupakan menu kelima dari aplikasi e-KMS. Pada menu ini kader Posyandu akan men-generate laporan setiap bulannya untuk mengetahui data balita. Tampilan generate laporan Posyandu dapat dilihat pada Gambar 12. 


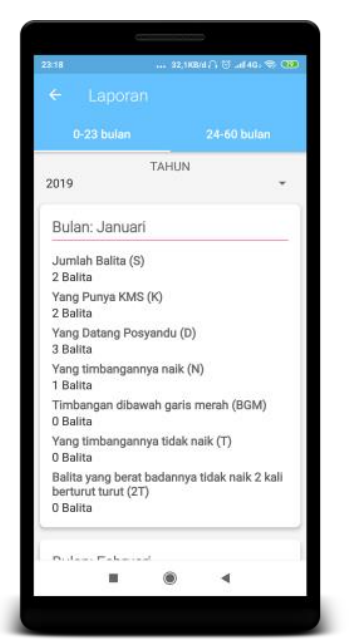

Gambar. 12. Tampilan Generate Laporan Posyandu

\subsection{Pengujian}

\subsubsection{Pengujian Fungsional}

Metode pengujian sistem dalam penelitian ini adalah menerapkan pengujian Black Box dengan menggunakan metode Equcalence Partitioning (EP). Pengujian ini berguna untuk membuktikan semua fungsi-fungsi pada aplikasi berjalan dengan baik. Dengan menggunakan pengujian ini dapat membuktikan antara masukan dan respon dapat diterima oleh pengguna. Pengujian dilakukan dengan membagi domain masukan dari program ke dalam kelas-kelas sehingga kasus uji diperoleh. Pengujian dapat dilakukan dengan mambagi kelas uji menjadi beberapa, yaitu pengujian versi Andoid, resolusi layar dan densitas layar, user interface, dan pengujian fungsi dari menu aplikasi.

\subsubsection{Pengujian Versi Android}

Pengujian aplikasi e-KMS dilakukan dengan tujuan untuk mengetahui apakah aplikasi dapat berjalan disemua versi yang diujikan. Pengujian di-lakukan dengan beberapa kriteria pengujian yang sudah ditentukan seperti : kelas uji, daftar pengujian, scenario uji, hasil yang diharapkan, dan hasil yang diperoleh setelah pengujian. Hasil pengujian aplikasi e-KMS disajikan pada Tabel 1.

\section{Tabel I. Hasil Pengujian Kompatibilitas Versi Android}

\begin{tabular}{llc}
\hline \multicolumn{1}{c}{ Skenario Uji } & \multicolumn{1}{c}{ Realisasi yang Diharapkan } & Hasil \\
\hline $\begin{array}{l}\text { Pengujian pasa Android versi 4.1 } \\
\text { (Jelly Bean) }\end{array}$ & $\begin{array}{l}\text { Kompatibel dengan Andoid } \\
\text { Pengujian pada Android versi 4.4 }\end{array}$ & Berhasil \\
$\begin{array}{l}\text { (KitKat) } \\
\begin{array}{l}\text { Pengujian pada Androlly Bean) } \\
\text { (Lolipop) }\end{array}\end{array}$ & $\begin{array}{l}\text { Kompatibel dengan Andoid } \\
\text { versi 4.4 (KitKat) }\end{array}$ & Berhasil \\
$\begin{array}{l}\text { Pengujian pada Android versi 6.0 } \\
\text { (Marshmallow) }\end{array}$ & $\begin{array}{l}\text { Kompatibel dengan Andoid } \\
\text { versi 5.0 (Lolipop) }\end{array}$ & Berhasil \\
& $\begin{array}{l}\text { Kompatibel dengan Andoid } \\
\text { versi 6.0 (Marshmallow) }\end{array}$ & Berhasil \\
\hline
\end{tabular}


Pengujian ukuran layar bertujuan untuk mengetahui apakah tampilan aplikasi dapat berjalan dengan baik pada ukuran layar Andorid yang diujikan. Adapun kriteria pengujian yang dilakukan adalah kelas uji, daftar pengujian, skenario uji, hasil yang diharapkan, hasil pengujian, pengujian ukuran layar disajikan pada Tabel 2.

Tabel 2. Hasil Pengujian Ukuran layar

\begin{tabular}{ccc}
\hline Skenario Uji & Realisasi yang Diharapkan & Hasil \\
\hline Pengujian pada Android & Tampilan terlihat sesuai atau baik pada & Berhasil \\
dengan resolusi 4 inch & Andoid dengan resolusi 4 inch & \\
Pengujian pada Android & Tampilan terlihat sesuai atau baik pada & Berhasil \\
dengan resolusi 5 inch & Andoid dengan resolusi 5 inch & \\
Pengujian pada Android & Tampilan terlihat sesuai atau baik pada & Berhasil \\
dengan resolusi 6 inch & Andoid dengan resolusi 6 inch & \\
\hline
\end{tabular}

\subsubsection{Pengujian User Interface}

Pengujian user interface bertujuan untuk mengetahui apakah tampilan pada aplikasi dapat berjalan sesuai dengan kebutuhan pengguna. Hasil pengujian user interface disajikan pada Tabel 3.

Tabel 3. Hasil Pengujian User Interface

\begin{tabular}{|c|c|c|}
\hline Skenario Uji & Realisasi yang Diharapkan & Hasil \\
\hline $\begin{array}{l}\text { Klik icon aplikasi e-KMS pada perangkat } \\
\text { Andorid Pengguna }\end{array}$ & Menampilkan layout splash screen & Berhasil \\
\hline Klik Button Menu "Profil Balita" & Menampilkan Layout "Profil Balita" & Berhasil \\
\hline Klik Button Menu "KMS dan Imunisasi" & $\begin{array}{l}\text { Menampilkan Layout "KMS dan } \\
\text { Imunisasi" }\end{array}$ & Berhasil \\
\hline Klik Button Menu "Kegiatan Posyandu" & $\begin{array}{l}\text { Menampilkan Layout "Kegiatan Po- } \\
\text { syandu" }\end{array}$ & Berhasil \\
\hline $\begin{array}{l}\text { Klik Button Menu "Tips dan Trik Me- } \\
\text { rawat Balita” }\end{array}$ & $\begin{array}{l}\text { Menampilkan Layout "Tips dan Trik } \\
\text { Merawat Balita" }\end{array}$ & Berhasil \\
\hline $\begin{array}{l}\text { Klik Button Menu "Mengelola Berat Ba- } \\
\text { dan Balita" }\end{array}$ & $\begin{array}{l}\text { Menampilkan Layout "Timbang } \\
\text { Balita" }\end{array}$ & Berhasil \\
\hline Klik Button Menu "Peta Posyandu" & $\begin{array}{l}\text { Menampilkan Layout “Peta Posyan- } \\
\text { du” }\end{array}$ & Berhasil \\
\hline Klik Button Menu “Tentang” & Menampilkan Layout "Tentang” & Berhasil \\
\hline $\begin{array}{l}\text { Klik Button Menu “Mengelola Berat Ba- } \\
\text { dan Balita” }\end{array}$ & $\begin{array}{l}\text { Menampilkan Layout "Timbang } \\
\text { Balita" }\end{array}$ & Berhasil \\
\hline
\end{tabular}

Berdasarkan hasil pengujian yang dilakukan didapatkan hasil seperti tersaji di Tabel 1, Tabel 2, dan Tabel 3. Dari ke-tiga Tabel yang ada didapatkan hasil yang baik, dimana pada pengujian versi Android Aplikasi mampu berjalan dengan baik pada setiap versi yang diujikan. Pada pengujian fungsi menu aplikasi dan user interface, aplikasi mampu berjalan dengan baik dan sesuai dengan yang diharapkan. 


\subsubsection{Pengujian Penerimaan Aplikasi oleh Pengguna}

Jumlah pengguna yang melakukan pengujian aplikasi sebanyak 25 orang, pengguna harus menguji setiap menu yang ada di aplikasi e-KMS. Kemudian pengguna harus mengisi kuisioner dan ada kriteria yang harus diisi oleh pengguna. Setelah melakukan pengujian, pengguna akan memberi penilaian dari masingmasing kriteria yang diuji.

Tabel 4. Hasil Pengujian Penerimaan Aplikasi Pada Pengguna

\begin{tabular}{|c|c|c|c|c|c|}
\hline \multirow{2}{*}{ No } & \multirow{2}{*}{ Kriteria Penilaian } & \multicolumn{4}{|c|}{ Kategori Penilaian } \\
\hline & & SS & $\mathrm{S}$ & TS & STS \\
\hline 1 & $\begin{array}{l}\text { Aplikasi mudah dimengerti } \\
\text { dan digunakan }\end{array}$ & 22 & 3 & 0 & 0 \\
\hline 2 & $\begin{array}{l}\text { Aplikasi memberi infomasi } \\
\text { yang jelas kepada pengguna }\end{array}$ & 20 & 5 & 0 & 0 \\
\hline 3 & $\begin{array}{l}\text { Aplikasi dapat menghitung } \\
\text { dan menentukan status gizi }\end{array}$ & 23 & 2 & 0 & 0 \\
\hline 4 & $\begin{array}{l}\text { Aplikasi dapat menyimpan } \\
\text { dan menentukan status gizi } \\
\text { balita }\end{array}$ & 25 & 0 & 0 & 0 \\
\hline 5 & $\begin{array}{l}\text { Aplikasi dapat membantu } \\
\text { kader Posyandu untuk mem- } \\
\text { buat laporan Posyandu setiap } \\
\text { bulannya }\end{array}$ & 22 & 3 & 0 & 0 \\
\hline & Persentase & 89,6 & 10,4 & 0 & 0 \\
\hline
\end{tabular}

Dari penilaian yang telah dilakukan oleh 25 pengguna, diperoleh data pengguna yang memilih SS (Sangat Setuju) sebanyak 89,6 \%, S (Sejutu) 10,4 \%, sedangkan untuk penilaian TS (Tidak Setuju) dan STS (Sangat Tidak Setuju) tidak ada yang memilih. Jadi dari keseluruhan data yang diperoleh, aplikasi mampu bekerja secara baik dan sesuai dengan kebutuhan pengguna

\section{SIMPULAN}

Dari penelitian yang telah dilakukan, dapat diambil simpulan sebagai berikut:

a. Aplikasi dapat menggantikan KMS (Kertu Menuju Sehat) yang berupa selebaran kertas menjadi aplikasi yang dapat mempermudah orang tua Balita untuk mengontrol kondisi balita.

b. Aplikasi mampu melakukan perhitungan untuk menentukan status gizi sesuai standar WHO (World Health Organization) tahun 2006 dan disajikan dalam bentuk grafik.

c. Proses penyimpanan data dapat tersimpan lebih baik dan dapat dikelola menjadi laporan Posyandu yang lebih akurat.

d. Dengan aplikasi ini orang tua Balita mendapat informasi cara merawat Balita.

e. Untuk penelitian lebih lanjut, aplikasi ini dapat dikembangkan pada platform lain seperti Apple IOS dan ditambahkan fitur yang mendukung moda online dan offline. 


\section{DAFTAR PUSTAKA}

[1] Peraturan Menteri Kesehatan RI, "Peraturan Menteri Kesehatan Republik Indonesia Nomor 42 tahun 2013 tentang Penyelenggaraan Imunisasi”, Jakarta, 2013.

[2] Nasrul Effendy, "Dasar-Dasar Keperawatan Kesehatan Masyarakat”, Jakarta: EGC, 1998.

[3] Roger S. Pressman, “Software Engineering : a practitioner's approach”, New York: McGraw-Hill, 2010.

[4] Rosa A.S dan M. Shalahuddin, "Rekayasa Perangkat Lunak Terstruktur Dan Berorientasi Objek", Bandung: Informatika, 2013. 